\title{
Resistance of Eight Different Clones of the Grape Cultivar Albariño to Plasmopara viticola
}

\author{
S. Boso, J. L. Santiago, and M. C. Martínez, Misión Biológica de Galicia (Consejo Superior de Investigaciones \\ Científicas), Apartado de Correos 28, 36080 Pontevedra (Spain)
}

\begin{abstract}
Boso, S., Santiago, J. L., and Martínez, M. C. 2004. Resistance of eight different clones of the grape cultivar Albariño to Plasmopara viticola. Plant Dis. 88:741-744.

Resistance to downy mildew (Plasmopara viticola) was studied in eight clones of the grape (Vitis vinifera) cultivar Albariño (confirmed as such by DNA and ampelographic analysis) growing at the Misión Biológica de Galicia, Spain. Resistance to downy mildew was quantified using an image processor. Some clones (CSIC-10 and CSIC-11) were more resistant than others to leaf infection by $P$. viticola. However, the susceptibility of grape clusters did not differ significantly among the clones.
\end{abstract}

Additional keywords: downy mildew resistance, image analysis, leaves

The grape (Vitis vinifera L.) cultivar Albariño is currently the most economically important grape cultivar in Galicia (northwestern Spain). Between 1987 and 1997, the area planted to Albariño increased from 237 to 1,978 ha. Because of abundant rainfall and cool temperatures, attacks of downy mildew (Plasmopara viticola) occur annually in Galicia. Fungicides have to be applied four times per year, which greatly increases costs of production and reduces the profits of growers. Thus, the availability of clones showing at least some resistance to downy mildew would be of commercial and ecological importance.

The first symptom of downy mildew on the leaves is the appearance of spots known as "oil spots". In the more advanced stages, a mosaic of spots appears. Both are easily identified. Symptoms on the grape clusters are also characteristic. When an attack occurs immediately after flowering, the grapes turn gray (gray rot). However, if the attack occurs when the grapes are about the size of peas, they become brown and shriveled (brown rot).

Cultivars of $V$. vinifera are very susceptible to downy mildew $(3,6,7,24,31)$, some more than others $(23,24)$. Clones of the same cultivar may also vary in susceptibility, but very few studies have examined clonal differences. The existence of many 300- to 400-year-old Albariño specimens in northwestern Spain suggests that these may have some resistance to disease, hav-

Corresponding author: S. Boso

E-mail: susanab@mbg.cesga.es

Accepted for publication 15 March 2004.

Publication no. D-2004-0517-01R

(C) 2004 The American Phytopathological Society ing survived the arrival of powdery mildew in $1850(11,19,26)$, phylloxera in 1882 $(11,14,18)$, and downy mildew in 1885 $(11,25)$. Many factors may be related to the resistance observed, as reported for other cultivars $(3,5-9,13,26,27)$.

Laboratory studies $(29,30)$ have shown that grape cultivars differ in level of resistance to downy mildew. However, these results cannot always be extrapolated to the field. In the field, plants are subject to multiple factors that influence the appearance and development of the disease, such as climate, soil conditions, and agricultural practices.

In 1987, Martínez et al. (20) began clonal selections of the cultivar Albariño. Forty-century-old specimens, all different clones, were found at different sites around Galicia. Ampelographic $(16,20)$ and DNA (17) studies were performed on each to determine whether there were any interclonal differences. All were identical in terms of their DNA (20), but at the ampelographic level, eight different groups were identified. The oldest and healthiest looking specimen was selected from each of these groups for planting in the same plot (10 repetitions per clone). Between 2000 and 2001, after the plants were established and in full production, an agronomic study was performed (2). In this study, significant differences were found for many important variables, including the weight of grapes per vine shoot, the quantity of must per grape, probable alcohol degree, and total acidity. The objective of the present work was to determine whether these clones varied in resistance to downy mildew.

\section{MATERIALS AND METHODS}

Plant material. This study was conducted during 2000, 2001, and 2002.
Plants, grafted onto Ritcher 110 stocks (10 repetitions per clone) were randomly arranged in the same plot in $1993(16,17,20)$. All plants were therefore subject to the same edaphoclimatic conditions and cultivation practices. Vines were pruned according to the sylvoz, system, and all were grown en espalier. The plot was located at the Misión Biológica de Galicia (CSIC), in the province of Pontevedra (northwestern Spain), the heart of the Rías Baixas Appelation Contrôlée region in which $75 \%$ of the vines are of the Albariño type. The clones studied were CSIC-1, CSIC-2, CSIC-6, CSIC-7, and CSIC-11 from northern Pontevedra province, CSIC-3 from northwestern Pontevedra province, and CSIC-9 and CSIC-10 from two locations in southern Pontevedra province.

Leaf sampling. Sampling was performed twice. The first samples were taken when early symptoms (light yellow "oil spots" with clear boundaries) appeared on the leaves and the second when later symptoms (mosaic of small, dark brown spots) appeared. Natural infections were used since the disease appears reliably in the study location.

Fifty arbitrarily selected, mature leaves with symptoms of downy mildew were examined from the 10 plants of each clone (five leaves per plant). These leaves were chosen from the upper and lower parts of the canopy as well as from the interior and exterior of the canopy. At the first sampling time (S1), each of these leaves was marked with a number (1 to 50). The leaves were not picked; instead, digital photographs were taken and examined using analySIS 3.0 software (Soft Imaging System GmbH, 1998). The number of spots per leaf was recorded, and their boundaries were marked. The leaf area occupied by each spot was then determined. Total leaf surface area was also determined.

When later symptoms (mosaic symptoms) were evident, sampling was performed again (S2) and photographs taken of the same leaves. The total surface area of each leaf, the area occupied by the spots, and the number of spots were recorded again.

From these data, the following relationships were calculated: severity of leaf infection (sum of the surface area of all spots/leaf surface area) and intensity of leaf infection (number of spots on each leaf/leaf surface area). 
Grape cluster sampling. Cluster samnumbers of healthy and diseased clusters on every vine were counted. Whole clusters were weighed, as were the parts of each that were affected by disease. From these data, we calculated severity of cluster infection (sum of the weight of diseased portions on each vine/total weight of the clusters of each vine $[\mathrm{g}]$ ) and incidence of cluster infection (number of diseased grape pling was performed during ripening. The

clusters per vine/total number of grape clusters examined).

Statistical analysis. Each variable was examined by analysis of variance (ANOVA) to determine whether there were any significant differences among the clones. For each variable, Fisher's protected test (minimum significant difference [MSD] method) was used to determine which clones were the most resistant and which were the most susceptible. All cal-

Table 1. Results of the analysis of variance for severity and intensity of leaf infections in eight clones of the grape cultivar Albariño for 3 years (2000, 2001, and 2002)

\begin{tabular}{|c|c|c|c|c|c|c|}
\hline \multirow{2}{*}{$\begin{array}{l}\text { Source of } \\
\text { variation }^{\text {a }}\end{array}$} & \multicolumn{3}{|c|}{ Severity of leaf infection } & \multicolumn{3}{|c|}{ Intensity of leaf infection } \\
\hline & 2000 & 2001 & 2002 & 2000 & 2001 & 2002 \\
\hline Clone at $\mathrm{S} 1$ & $\mathrm{NS}^{\mathrm{b}}$ & NS & NS & $* *$ & NS & $*$ \\
\hline Clone at $\mathrm{S} 2$ & $* *$ & $* *$ & $* *$ & $* *$ & $* *$ & $*$ \\
\hline Clone & $*$ & $*$ & $* *$ & $* *$ & $* *$ & $* *$ \\
\hline Sample S1+S2 & $* *$ & $* *$ & $* *$ & $* *$ & $* *$ & $* *$ \\
\hline Clone $\times$ sample & NS & $* *$ & $* *$ & $* *$ & $* *$ & $* *$ \\
\hline
\end{tabular}

a Sources of variation were: Clone at S1, first sampling time; S2, second sampling time; Clone, clones for first and second sample combined; Sample S1+S2, both sampling times combined; Clone $x$ sample, interaction of clone by sampling time.

${ }^{\mathrm{b}} \mathrm{NS}$, not significant; *, significant at the 0.05 probability level; **, significant at the 0.01 probability level.

Table 2. Mean value of each grape clone for severity of leaf infection at sampling times S1 and S2 and average for the years 2000, 2001, and 2002

\begin{tabular}{|c|c|c|c|c|c|}
\hline Clones & Observations & Years & $S 1^{a}$ & $\mathbf{S} 2^{\mathbf{a}}$ & Mean \\
\hline CSIC-1 & 50 & $\begin{array}{c}2000 \\
2001 \\
2002 \\
\text { Mean }^{\mathrm{b}}\end{array}$ & $\begin{array}{l}0.072 \\
0.030 \\
0.043 \\
0.048\end{array}$ & $\begin{array}{l}0.219 \\
0.084 \\
0.313 \\
0.205\end{array}$ & $\begin{array}{l}0.145 \\
0.060 \\
0.174 \\
0.126\end{array}$ \\
\hline CSIC-2 & 50 & $\begin{array}{c}2000 \\
2001 \\
2002 \\
\text { Mean }^{\text {b }}\end{array}$ & $\begin{array}{l}0.149 \\
0.020 \\
0.044 \\
0.071\end{array}$ & $\begin{array}{l}0.294 \\
0.054 \\
0.298 \\
0.215\end{array}$ & $\begin{array}{l}0.221 \\
0.045 \\
0.162 \\
0.142\end{array}$ \\
\hline CSIC-3 & 50 & $\begin{array}{c}2000 \\
2001 \\
2002 \\
\text { Mean }^{\text {b }}\end{array}$ & $\begin{array}{l}0.124 \\
0.012 \\
0.025 \\
0.053\end{array}$ & $\begin{array}{l}0.227 \\
0.044 \\
0.310 \\
0.193\end{array}$ & $\begin{array}{l}0.175 \\
0.038 \\
0.168 \\
0.127\end{array}$ \\
\hline CSIC-6 & 50 & $\begin{array}{c}2000 \\
2001 \\
2002 \\
\text { Mean }^{\text {b }}\end{array}$ & $\begin{array}{l}0.109 \\
0.012 \\
0.027 \\
0.049\end{array}$ & $\begin{array}{l}0.154 \\
0.043 \\
0.182 \\
0.126\end{array}$ & $\begin{array}{l}0.131 \\
0.030 \\
0.099 \\
0.086\end{array}$ \\
\hline CSIC-7 & 50 & $\begin{array}{c}2000 \\
2001 \\
2002 \\
\text { Mean }^{\text {b }}\end{array}$ & $\begin{array}{l}0.110 \\
0.017 \\
0.048 \\
0.058\end{array}$ & $\begin{array}{l}0.181 \\
0.048 \\
0.226 \\
0.151\end{array}$ & $\begin{array}{l}0.145 \\
0.026 \\
0.110 \\
0.093\end{array}$ \\
\hline CSIC-9 & 44 & $\begin{array}{c}2000 \\
2001 \\
2002 \\
\text { Mean }^{\text {b }}\end{array}$ & $\begin{array}{l}0.057 \\
0.028 \\
0.038 \\
0.041\end{array}$ & $\begin{array}{l}0.144 \\
0.076 \\
0.146 \\
0.122\end{array}$ & $\begin{array}{l}0.100 \\
0.050 \\
0.087 \\
0.079\end{array}$ \\
\hline CSIC-10 & 50 & $\begin{array}{c}2000 \\
2001 \\
2002 \\
\text { Mean }^{\text {b }}\end{array}$ & $\begin{array}{l}0.149 \\
0.016 \\
0.031 \\
0.065\end{array}$ & $\begin{array}{l}0.172 \\
0.047 \\
0.203 \\
0.140\end{array}$ & $\begin{array}{l}0.160 \\
0.031 \\
0.112 \\
0.101\end{array}$ \\
\hline CSIC-11 & 50 & $\begin{array}{c}2000 \\
2001 \\
2002 \\
\text { Mean }^{\text {b }}\end{array}$ & $\begin{array}{l}0.059 \\
0.008 \\
0.044 \\
0.037\end{array}$ & $\begin{array}{l}0.181 \\
0.043 \\
0.166 \\
0.130\end{array}$ & $\begin{array}{l}0.120 \\
0.012 \\
0.095 \\
0.075\end{array}$ \\
\hline Mean & & $\begin{array}{l}2000 \\
2001 \\
2002\end{array}$ & $\begin{array}{l}0.117 \\
0.017 \\
0.038\end{array}$ & $\begin{array}{l}0.185 \\
0.054 \\
0.230\end{array}$ & $\begin{array}{l}0.151 \\
0.036 \\
0.125\end{array}$ \\
\hline $\operatorname{LSD}_{0.05}$ & & $\begin{array}{l}2000 \\
2001 \\
2002\end{array}$ & $\begin{array}{l}0.161 \\
0.015 \\
0.022\end{array}$ & $\begin{array}{l}0.066 \\
0.022 \\
0.095\end{array}$ & $\begin{array}{l}0.087 \\
0.020 \\
0.044\end{array}$ \\
\hline
\end{tabular}

\footnotetext{
${ }^{\text {a }}$ S1, first sampling time; $\mathrm{S} 2$, second sampling time.
}

${ }^{\mathrm{b}}$ Mean, average of 3 years. culations were performed using SAS V8.1 software (SAS Institute, Cary, NC; 2000). The sources of variation in the leaf samples were clone and sampling time.

\section{RESULTS}

Severity of leaf disease. Disease severity was greatest at S2 for each year of the study. No significant differences were found among the clones at S1, although there were differences at S2. The interaction of clone $\times$ sampling time was significant for 2001 and 2002, but not for 2000 (Table 1). In the year 2000, all clones were more affected at S2 than at S1, but the relative difference between them was constant; in other words, the clones affected at S1 were generally the same ones affected at S2. Comparing data for S2 (Table 2) with those of the two sampling times together $(\mathrm{S} 1+\mathrm{S} 2)$, clones CSIC-1, CSIC-2, and CSIC-3 were the most affected by the disease, whereas the least affected were CSIC-6, CSIC-9, and CSIC-11 (Table 2).

Intensity of leaf disease. There were significant differences between sample times each year. Intensity was greatest at S2 in 2001 and 2002, whereas in 2000 intensity was greatest at S1. The interaction of clone $\times$ sampling time was significant for all 3 years, i.e., the clone with the greatest or least intensity of disease was not the same at $\mathrm{S} 1$ as at $\mathrm{S} 2$.

Significant differences were seen among clones, except at S1 in 2001 (Table 1). At S1, clones CSIC-1 and CSIC-10 showed significantly less disease intensity than other clones (Table 3).

At S2 (Table 3), CSIC-1 had the greatest disease intensity, followed by CSIC-2 and CSIC-7. At the opposite extreme, CSIC-10 and CSIC-6 showed fewest spots; their behavior was significantly different from that of the other clones.

If the data for $\mathrm{S} 1$ and $\mathrm{S} 2$ are taken together (Table 3), clones CSIC-1 and CSIC2 showed the highest disease intensity, and CSIC-6 the lowest.

When combining disease intensity and severity (Fig. 1), CSIC-1 and CSIC-2 appeared to be the most sensitive to downy mildew, whereas CSIC-9, CSIC-11, CSIC10, and CSIC-6 were the most resistant. CSIC-3 showed high disease severity but low intensity.

Clusters. No differences in severity or incidence of brown rot were seen among the clones in any of the 3 years (data not shown).

\section{DISCUSSION}

In this study, clones of the grape cultivar Albariño were found to vary in their resistance to downy mildew. In general, and independent of sampling time, CSIC-9, CSIC-6, CSIC-10, and CSIC-11 were the most resistant clones, and CSIC-1, CSIC2 , and CSIC-3 the most susceptible. The interaction at clone $\times$ sampling was significant for the majority of years. Disease 
intensity in CSIC-2 was significantly less at $\mathrm{S} 1$ than in the remaining clones. This is an artifact of our rating system, however, since disease intensity was quantified by relating the number of spots to the size of the leaf. CSIC-2 had very large leaves with large but few spots (at S1). At S2, CSIC-2 showed the greatest disease intensity and severity. Therefore, CSIC-2 should be considered the most susceptible clone to downy mildew.

CSIC-1 was, in general, the clone with lowest intensity and severity of disease at $\mathrm{S} 1$, but was one of the most affected at S2. This clone is therefore relatively resistant to early infection and more susceptible to late infection. If this result is confirmed by further research, early-season fungicide sprays can be reduced.

At S2, all clones showed the mosaic pattern except for CSIC-1. CSIC-9 was among the most susceptible to early infection, but among the most resistant to late infection. CSIC- 6 and CSIC-11 were the most resistant clones, to both early and late infection.

Several different methods have been used for quantifying the resistance of vine cultivars to downy mildew $(1,3,7,10,21$, 28,30). Staudt and Kassemeyer (30) based their procedure on estimating the percentage of leaf area affected by the disease, although these authors inoculated the leaves and later tested resistance in the laboratory under conditions of controlled light and temperature. The majority of authors $(3,7,10,21,28)$ measured disease development using a visual scale. In the present work, we estimated the resistance of each clones under field conditions using image processing software in order to detect the amount of surface affected, thereby removing the subjectivity of visual rating.

In our study, two sampling times ( $\mathrm{S} 1$ and S2) were employed rather than just one as in other studies $(1,10,28)$. This allowed us to determine how the disease progressed over the vegetative cycle and as a function of the weather conditions each year. It also revealed that some clones that were relatively resistant to early attacks were more sensitive to late attacks (CSIC1 ) or vice versa (CSIC-9).

The method used in this study enabled us to quantify the level of resistance of different cultivars, but did not explain the mechanisms underlying the differences observed. Some authors $(7,12,22,24,25,27)$ indicated that differences among cultivars could be due to inherent characteristics; the same phenomenon may occur with clones. Ruíz Castro (27) observed that some cultivars that were sensitive to spring attacks later acquired greater resistance. Other authors $(3,25)$ indicated that resistance to downy mildew was a result of factors that limited the spread of the mycelium (e.g., leaf veins prevent its advance) or hampered the penetration of the zoospores through stomata. Other studies
$(15,27)$ showed that very hairy leaves prevented conidia from making contact with the leaf lamina. However, previous ampelographic studies of the leaves of clones

used in our study $(16,20)$ showed there were no significant differences among them with respect to hairiness, and that all had a high mean density of reclining hairs.

Table 3. Mean value $(\times 1,000)$ of each grape clone for intensity of leaf infection at sampling times S1 and S2 for the years 2000, 2001, and 2002

\begin{tabular}{|c|c|c|c|c|c|}
\hline Clones & Observations & Years & $\mathbf{S 1}^{\mathbf{a}}$ & $\mathbf{S} 2^{\mathbf{a}}$ & Mean \\
\hline CSIC-1 & 50 & $\begin{array}{c}2000 \\
2001 \\
2002 \\
\text { Mean }^{\text {b }}\end{array}$ & $\begin{array}{l}0.053 \\
0.203 \\
0.135 \\
0.195\end{array}$ & $\begin{array}{l}0.074 \\
0.503 \\
9.046 \\
4.811\end{array}$ & $\begin{array}{l}0.063 \\
0.304 \\
4.447 \\
1.604\end{array}$ \\
\hline CSIC-2 & 50 & $\begin{array}{c}2000 \\
2001 \\
2002 \\
\text { Mean }^{\text {b }}\end{array}$ & $\begin{array}{l}0.000 \\
0.120 \\
0.588 \\
0.236\end{array}$ & $\begin{array}{l}0.247 \\
1.299 \\
1.016 \\
0.854\end{array}$ & $\begin{array}{l}0.123 \\
1.600 \\
0.788 \\
0.837\end{array}$ \\
\hline CSIC-3 & 50 & $\begin{array}{c}2000 \\
2001 \\
2002 \\
\text { Mean }^{\text {b }}\end{array}$ & $\begin{array}{l}0.183 \\
0.630 \\
0.489 \\
0.434\end{array}$ & $\begin{array}{l}0.001 \\
0.950 \\
0.971 \\
0.640\end{array}$ & $\begin{array}{l}0.092 \\
0.752 \\
0.730 \\
0.524\end{array}$ \\
\hline CSIC-6 & 50 & $\begin{array}{c}2000 \\
2001 \\
2002 \\
\text { Mean }^{\text {b }}\end{array}$ & $\begin{array}{l}0.221 \\
0.320 \\
0.472 \\
0.337\end{array}$ & $\begin{array}{c}0 \\
0.535 \\
0.845 \\
0.460\end{array}$ & $\begin{array}{l}0.110 \\
0.416 \\
0.645 \\
0.390\end{array}$ \\
\hline CSIC-7 & 50 & $\begin{array}{c}2000 \\
2001 \\
2002 \\
\text { Mean }^{\text {b }}\end{array}$ & $\begin{array}{l}0.189 \\
1.200 \\
0.519 \\
0.636\end{array}$ & $\begin{array}{l}0.094 \\
1.916 \\
0.562 \\
0.857\end{array}$ & $\begin{array}{l}0.141 \\
1.600 \\
0.534 \\
0.758\end{array}$ \\
\hline CSIC-9 & 44 & $\begin{array}{c}2000 \\
2001 \\
2002 \\
\text { Mean }^{\text {b }}\end{array}$ & $\begin{array}{l}0.198 \\
0.980 \\
0.589 \\
0.589\end{array}$ & $\begin{array}{c}0 \\
1.058 \\
0.604 \\
0.554\end{array}$ & $\begin{array}{l}0.099 \\
1.000 \\
0.596 \\
0.565\end{array}$ \\
\hline CSIC-10 & 50 & $\begin{array}{c}2000 \\
2001 \\
2002 \\
\text { Mean }^{\text {b }}\end{array}$ & $\begin{array}{l}0.088 \\
0.020 \\
0.328 \\
0.145\end{array}$ & $\begin{array}{c}0 \\
0.106 \\
0.689 \\
0.265\end{array}$ & $\begin{array}{l}0.044 \\
0.050 \\
0.499 \\
0.197\end{array}$ \\
\hline CSIC-11 & 50 & $\begin{array}{c}2000 \\
2001 \\
2002 \\
\text { Mean }^{\text {b }}\end{array}$ & $\begin{array}{l}0.235 \\
0.532 \\
0.378 \\
0.381\end{array}$ & $\begin{array}{l}0.057 \\
0.943 \\
0.463 \\
0.487\end{array}$ & $\begin{array}{l}0.146 \\
0.612 \\
0.414 \\
0.388\end{array}$ \\
\hline Mean & & $\begin{array}{l}2000 \\
2001 \\
2002\end{array}$ & $\begin{array}{l}0.169 \\
0.235 \\
0.435\end{array}$ & $\begin{array}{l}0.103 \\
1.060 \\
1.940\end{array}$ & $\begin{array}{l}0.130 \\
0.185 \\
0.236\end{array}$ \\
\hline $\operatorname{LSD}_{0.05}$ & & $\begin{array}{l}2000 \\
2001 \\
2002\end{array}$ & $\begin{array}{c}0.1 \\
0.08 \\
0.09\end{array}$ & $\begin{array}{l}0.04 \\
0.09 \\
0.05\end{array}$ & $\begin{array}{l}0.04 \\
0.07 \\
0.06\end{array}$ \\
\hline
\end{tabular}

a S1, first sampling time; S2, second sampling time.

${ }^{\mathrm{b}}$ Mean, average of 3 years.

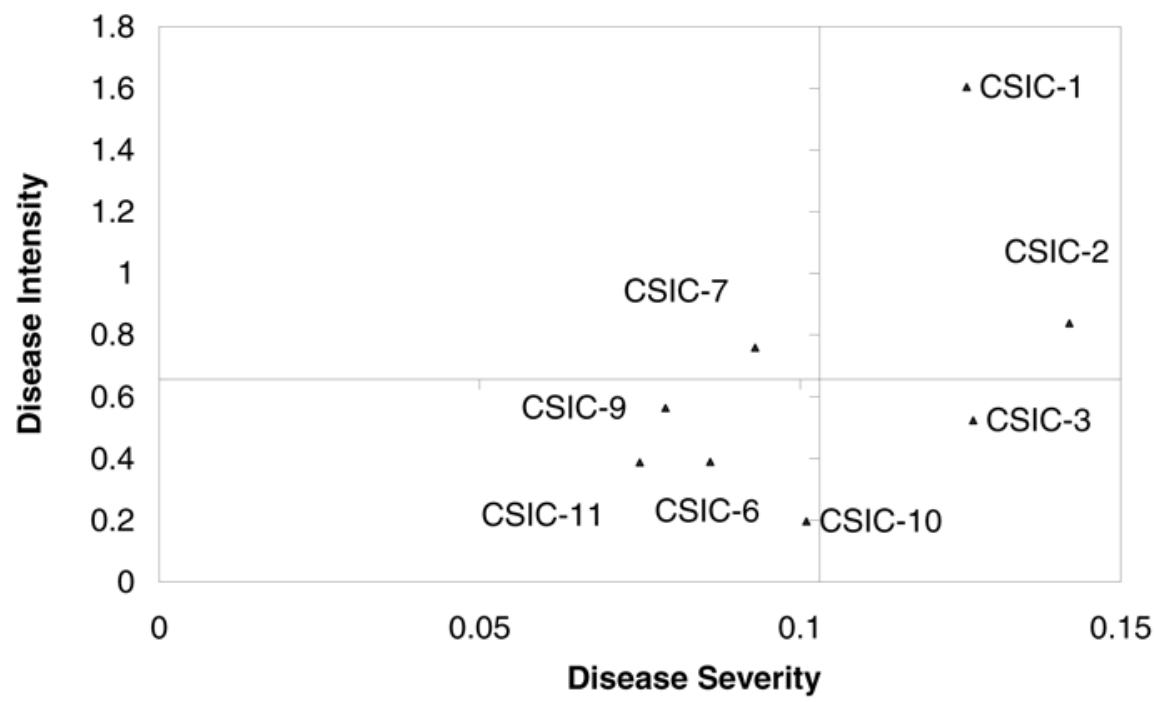

Fig. 1. Mean values of disease intensity and severity for the 3 years of the study, combining the two sampling times. 
Other factors that affect disease development include temperature (temperatures above $30^{\circ} \mathrm{C}$ inhibit the germination of conidia), wind (which favors the dissemination of zoospores), and mechanical disturbance of soil close to flowering time, which seems to disperse the fungus $(6,22)$. However, these factors were not the cause of the differences seen among the clones used in this study, since all were grown under the same soil, climate, and cultivation conditions.

The use of more resistant clones could help reduce the number of fungicide treatments required and therefore reduce production costs. Environmental pollution would also be reduced, as would fermentation problems caused by the often excessive use of pesticides. Resistant clones are needed by the wine industry because of the large crop losses this disease causes and because of its effect on wine quality $(3,4,23,25,29,32,33)$. Since the disease is strongly linked to environmental conditions, and since some clones appear to be more resistant than others, it might be possible to recommend different clones for different places.

Finally, if it is definitively demonstrated that one or more of these clones is highly resistant to downy mildew, they could provide valuable material from which to seek markers for resistance and be of use in genetic transformation programs.

\section{LITERATURE CITED}

1. Bassler, P. 1998. Expérimentation avec le cépage Regent en Suisse orientale. Rev. Suisse Vitic. Arboric. Hortic. 30:353-355.

2. Boso, S. 2002. Estudio sobre el nivel de resistencia a mildiu, oídio y botrytis, en distintos clones de la variedad albariño (Vitis vinifera L.), y sus características agronómicas. Tesis de Licenciatura. Facultad de Biología, Universidad de Vigo.

3. Boubals, D. 1959. Contribution á l'étude des causes de la résistance de Vitacées au mildiou de la vigne (Plasmapora viticola (B. et $C$.) Berl. et de T.) et de leur mode de transmission héréditaire. Thèse de doctorat dés sciences. Ann. Amélior. Plant. 1-236.

4. Boubals, D. 1961. Etudes des causes de la résistance des Vitacées à l'oödium de la Vigne Uncinula necator (Schw.) Burr. Et de leur mode de transmission héréditaire. Ann. Amélior. Plant. 11:401-500.

5. Branas, J. 1974. Viticulture. Imp. Déhan, Montpellier.

6. Föex, G. 1891. Cours complet de Viticulture. 3éme. ed. G. Masson, Libraire-Editeur, Paris.

7. Galet, P. 1977. Les maladies et les parasites de la vigne, tome I: Les maladies dues á des végétaux. Imp. Le Paysan du Midi., Montpellier.

8. Galet, P. 1995. Précis de Pathologie viticole. 2éme ed. Imprimerie JF Impression, Montpellier.

9. Hidalgo, L. 1993. Tratado de viticultura general. Ed. Mundi-Prensa, Madrid.

10. Horsfall, J. G., and Cowling, E. B. 1978. Pathometry: Measurement of plant disease. Plant Disease: An Advanced Treatise, vol. II. J. G. Horsfall and E. B. Cowling, ed. Academic Press, New York

11. Huetz de Lemps, A. 1967. Vignobles et vins du Nord-Ouest de 1'Espagne. Tomos I-II. Institut de Gèographie. Faculté des Lettres, Bordeaux.

12. Huglin, P. 1986. Biologie et écologie de la vigne. Ed. Payot Lausanne, París.

13. Husfeld, B. 1933. Ueber die Züchtung Plasmopara Widerstandfähiger Reden. Gartenbauw 7:15-92.

14. Jhonson, H. 1990. Une histoire mondiale du vin. Ed. Hachette, París.

15. Kortekamp, A., Wind, R., and Zyprian, E. 1999. The role of hairs on the wettability of grapevine (Vitis spp.) leaves. Vitis 38:101-105.

16. Loureiro, M. D. 1999. Descripción ampelográfica de cepas de Vitis vinífera, L. denominadas Albariño, procedentes de distintos puntos de la geografía gallega. Tesis doctoral. Universidad de Santiago de Compostela, Santiago de Compostela.

17. Loureiro, M. D., Martínez, M. C., Boursiquot, J. M., and This, P. 1998. Molecular marker analysis of Vitis vinífera "Albariño" and some similar grapevine cultivars. J. Am. Soc. Hortic. Sci. 123:842-848.

18. Marcilla, J. 1968. Tratado práctico de Viticultura y Enología Españolas. Tomo I, Viticultura.
Ed. Saeta, Madrid.

19. Marcilla, J. 1968. Tratado práctico de Viticultura y Enología Españolas. Tomo II, Viticultura. Ed. Saeta, Madrid.

20. Martínez, M. C., Loureiro, M. D., and Mantilla, J. L. G. 1994. Importancia y validez de distintos parámetros ampelométricos de hoja adulta utilizados en la distinción de cultivares de Vitis vinífera L. Inv. Agric. Prod. Prot. Veg. 9:377-189.

21. Office international de la vigne et du vin (OIV). 1983. Le code des caractères descriptifs des variétés et espéces de Vitis. Ed. Dedon, París.

22. Pearson, R. C., and Goheen, A. C. 1996. Plagas y enfermedades de la vid. Ed. MundiPrensa, Madrid.

23. Pérez Marín, J. L. 1992. Los parásitos de la vid. Estrategias de protección razonada. Ministerio de Agricultura, Pesca y Alimentación. Ediciones Mundi-Prensa, Madrid.

24. Ravaz, L. 1914. Le mildiou. Masson éd, París.

25. Ribereau-Gayon, J., and Peynaud, E. 1971 Traité d'ampélologie. Sciencies et Techniques de la vigne (Tome I, Biologie de la Traité vigne, sols de vignobles). Ed. Dunot, París.

26. Reynier, A. 1989. Manual de Viticultura. 4th edición. Ed. Mundi-Prensa, Madrid.

27. Ruíz Castro, A. 1965. Plagas y enfermedades de la vid. Instituto Nacional de Investigaciones Agrarias (INIA), Madrid.

28. Spring, J.-L., Jermini, M., Maigre, D., and Murisier, F. 1998. Rev. Suisse Vitic. Arboric. Hortic. 30:347-351.

29. Staudt, G. 1997. Evaluation of resistance to grapevine downy mildew (Uncínula necator) in accessions of Vitis species. Vitis 36:151154.

30. Staudt, G., and Kassemeyer, H.-H. 1995. Evaluation of downy mildew (Plasmopara viticola) resistance in various accessions of wild Vitis species. Vitis 34:225-228.

31. Viala, P. 1893. Les maladies de la vigne, 3éd. Masson, Paris.

32. Wang, Y., Liu, Y., He, P., Chen, J., Laminkara, O., and Lu, J. 1995. Evaluation of foliar resistance to Uncinula necator in Chinese wild Vitis species. Vitis 34:159-164.

33. Ypema, H. L., and Gubler, W. D. 2000. The distribution of early season grapevine shoots infected by Uncinula necator from year to year: A case study in two California vineyards. Am. J. Enol. Vitic. 51:1-6. 